\title{
Testing Carbohydrate Substance as Flash Based Flipbook Learning Media
}

\author{
Nida Ulfia Husna Fadhila ${ }^{*}$, Sulistiyawati \\ Biology Education Department, Faculty of Science and Technology, UIN Sunan Kalijaga, \\ Jl. Marsda Adisucipto No 1 Yogyakarta 55281, Indonesia. Tel. +62-274-540971, Fax. +62-274-519739. \\ "Email: niddnidda@gmail.com
}

\begin{abstract}
This study aims to produce a flash-based flipbook and find out the quality of flash-based flipbook products that are suitable for use as supporting learning media. The study consisted of preliminary research in the form of carbohydrate test practicum consisting of barfoed test, benedict test and iod / lugol test. The results of the study were developed into flash-based flipbook using macromedia flash and microsoft word 2010 through the data entry stage to the developer software, preparation of layouts and provision of activities on flash-based flipbook. The final product in the form of flipbook is flash-based. Flash-based flipbook was assessed by 1 material expert, 1 media expert, 1 science teacher, 3 peer reviewers, and tested on 10 junior high school students. The results of the evaluation of flashbased flipbook according to material experts were $90.87 \%$ (Very good), media experts $88.10 \%$ (Very good), peer reviewers $93.39 \%$ (Very good), biology teachers $75.00 \%$ (Good), and $85.6 \%$ (Very good) student response. Based on this assessment, the flash-based flipbook that was developed is worthy of being used as a source of learning biology.
\end{abstract}

Keywords: Carbohydrate test, Flash based, Flipbook development, Learning media

\section{INTRODUCTION}

Improving the quality of education from year to year is always pursued by developing learning media. The aim is to facilitate learning so as to make it easier for students to understand the material (Gestaning, 2014). Learning media can bring up problems to be studied further and solved by students in their learning (Dzamarah and Aswan, 2006). This interaction between students and the media is actually a real form of learning action (Degeng, 1989). But currently the use of learning media can still be said to be minimal or not innovative, because of the limited ability of teachers to find resources to get more interesting learning media. The use of media that is often used in schools is in the form of textbooks, LKS and power points. Teachers need to use learning media that can generate motivation and learning activities and bring psychological influence on students (Arsyad, 2008).

In the subject matter of the Food Digestion System in Humans there is a sub-material content of food that explains carbohydrates. Carbohydrates are the most common food substances in everyday life, so they need specific explanations to be easily understood by students to be linked to everyday life. So far at the secondary school level, the practicum carried out on the subject matter of the Food Digestion System in Humans is the Food Ingredient Test, there is no practicum on the specific topic of carbohydrate substance testing. This topic is important for students to know that the food ingredients that contain carbohydrates are not only rice. Therefore, through this research will be developed flash-based flipbook learning media with carbohydrate substance test discussion so that it can help students to learn material taught by the teacher not only when in school, but can be anytime and anywhere.

The media offered in the form of flash-based flipbook which is teaching material is independent (self-learning materials) so that students can review the material at any time if they need it. Flipbook is the development of e-books where e-books are only digital books while flipbooks are in the form of books that can be opened page by page. The presence of a flipbook will make students seem to read a real book, so get a better visual experience. Facilities offered in using flash-based flipbook media such as presentation media, animation, images and videos are expected to make students not bored in accessing them. The ability of Macromedia Flash to make presentations supports multimedia insertion such as sound, image and ease of operation (Hasrul, 2011). The ease of operation in the use of flash-based media is an interactive key function that facilitates teaching and learning activities as desired (Chandra, 2004).

\section{MATERIAL AND METHODS}

\section{Media Development Design}

The activity at this stage is the creation of flash-based flipbook content based on the elaboration of the structural framework to produce the initial product design. The software needed to create this media is Microsoft Windows XP and Windows 7 as the Operating System and Macromedia Flash 8 as software to create media. 


\section{Identification and Capture of Carbohydrate Test}

The tools used include test tubes, test tube shelves, test tube clamps, pipettes, measuring cups, and spirtus bunsen burners. The ingredients used include avocado seed powder, durian seed powder, jackfruit seed powder, barfoed reagent, benedict reagent and iodine reagent. The first stage is making powder from avocado seeds, durian seeds, and jackfruit seeds. The second stage is a qualitative test of carbohydrates which is a test to determine whether there is carbohydrate content.

\section{Product Trial}

The product testing phase consists of reviewers, peer reviewers and limited trials. The assessment was conducted by 1 material expert lecturer, 1 media expert lecturer, 3 peer reviewers and 1 science teacher.

\section{Product Assessment}

The product assessment design in this development study uses descriptive descriptions. The product quality assessment subjects in this study were 1 material expert, 1 media expert, 3 peer reviewers, 1 science teacher and 10 junior high school students. The data used in this study are qualitative data and quantitative data. The instrument in this study is a questionnaire about the quality of flash-based flipbook. Data analysis techniques used were media development process data in the form of descriptive data from experts, IPA teachers, and peer reviewers, as well as the resulting product quality data were analyzed by converting qualitative data into quantitative data.

\section{RESULTS AND DISCUSSION}

\section{Results}

\section{Results Flash-based flipbook design}

The stage of designing flipbook is flash-based using Macromedia Flash and Microsoft Word 2010. Both software are selected as learning media for flashbookbased flash development because of their ease of use and software that is familiar to teachers and students.

\section{Results of identification and shooting of carbohydrate test results can be seen in table 1.}

Table 1. Results of carbohydrate test research.

\begin{tabular}{|c|c|c|c|}
\hline No & Test of Carbohydrate & Test Results & \\
\hline 1. & $\begin{array}{l}\text { Test Barfoed } \\
\text { Barfoed test is a qualitative test of carbohydrates using reagents in the form } \\
\text { of solutions containing kuprisulfat and acetic acid in water. The reactants } \\
\text { react with reducing sugars (monosaccharides) so that the resulting red } \\
\text { carbon dioxide deposits are produced. }\end{array}$ & & \\
\hline 2. & $\begin{array}{l}\text { Test Benedict } \\
\text { Benedict test is a qualitative test of carbohydrates using reagents in the } \\
\text { form of solutions containing kuprisulfat, sodium carbonate and } \\
\text { natriumsitrat. Glucose can reduce } \mathrm{Cu}++ \text { from kuprisulfat ion to } \mathrm{Cu}+\text { ion } \\
\text { which then settles as } \mathrm{Cu} 2 \mathrm{O} \text {. The precipitate formed can be green, yellow, } \\
\text { or brick red. The color of the sediment depends on the number of } \\
\text { carbohydrates examined. }\end{array}$ & & \\
\hline 3. & $\begin{array}{l}\text { Lugol Test } \\
\text { The iodine test is a testing method for polysaccharide molecules. Starch is } \\
\text { a polysaccharide containing two main components, namely amylose and } \\
\text { amylopectin. In the test results, the material samples showed positive } \\
\text { results on the iodine test, indicated by the change in color to blackish blue. }\end{array}$ & apukat & nangke \\
\hline
\end{tabular}




\section{Product Testing Results}

\section{a. Expert Assessment}

Table 2. Product assessment by material experts.

\begin{tabular}{|c|c|c|}
\hline Aspect & Input & Follow-up \\
\hline Learning & $\begin{array}{l}\text { Added molecular structure } \\
\text { of carbohydrates }\end{array}$ & Already added \\
\hline Truth Contents & $\begin{array}{l}\text { Added reactions that occur } \\
\text { at the test stage }\end{array}$ & Already added \\
\hline
\end{tabular}

Table 3. Product assessment by media experts.

\begin{tabular}{|c|c|c|}
\hline Aspect & Input & Follow-up \\
\hline Display & $\begin{array}{l}\text { The front cover doesn't } \\
\text { need the previous button }\end{array}$ & $\begin{array}{l}\text { Already } \\
\text { repaired }\end{array}$ \\
\hline Programming & $\begin{array}{l}\text { Consistent in the } \\
\text { instructions section that } \\
\text { appears when clicked } \\
\text { using the keyboard }\end{array}$ & $\begin{array}{l}\text { Already } \\
\text { repaired }\end{array}$ \\
\hline
\end{tabular}

Table 4. Product assessment by peer reviewers.

\begin{tabular}{|c|c|c|}
\hline Aspect & Input & Follow-up \\
\hline Learning & $\begin{array}{l}\text { Need to add questions for } \\
\text { evaluation }\end{array}$ & $\begin{array}{l}\text { Already } \\
\text { added }\end{array}$ \\
\hline Display & $\begin{array}{l}\text { On the cover page the } \\
\text { button/button on the left is } \\
\text { removed The consistency of the } \\
\text { distance between paragraphs is } \\
\text { improved Change the color on } \\
\text { the page background because } \\
\text { it's too flashy }\end{array}$ & $\begin{array}{l}\text { Already } \\
\text { repaired }\end{array}$ \\
\hline
\end{tabular}

b. Product Quality Assessment Results

Table 5. Results of product quality assessment by material experts.

\begin{tabular}{lllll}
\hline Aspect & $\begin{array}{l}\text { Ideal } \\
\text { Highst } \\
\text { Score }\end{array}$ & $\begin{array}{l}\text { Score of } \\
\text { Assessmnt } \\
\text { Results }\end{array}$ & $\begin{array}{l}\text { Percente } \\
(\%)\end{array}$ & Quality \\
\hline Learning & 28 & 25 & 89,29 & SB \\
Truth content & 24 & 22 & 91,67 & SB \\
Linguistic & 12 & 11 & 91,67 & SB \\
Total & 64 & 58 & 90,87 & SB \\
\hline
\end{tabular}

Description: SB (Very Good)

The quality of flash-based flipbook according to material experts is very good with a percentage of $90.87 \%$. The results of product quality assessment according to media experts are presented in table 6 .

Table 6. Results of product quality assessment by media experts.

\begin{tabular}{lllll}
\hline Aspect & $\begin{array}{l}\text { Ideal } \\
\text { Highest } \\
\text { Score }\end{array}$ & $\begin{array}{l}\text { Score of } \\
\text { Assessment } \\
\text { Results }\end{array}$ & $\begin{array}{l}\text { Percentage } \\
(\boldsymbol{\%})\end{array}$ & Quality \\
\hline Learning & 8 & 7 & 87,50 & SB \\
Display & 20 & 18 & 90,00 & SB \\
Progammig & 12 & 10 & 83,33 & SB \\
Linguistic & 12 & 11 & 91,67 & SB \\
Total & 52 & 46 & 88,1 & SB \\
\hline
\end{tabular}

Description: SB (Very Good).
The quality of flashbook based on flash carbohydrate test material according to media experts is very good with a percentage of $88.1 \%$. The results of the assessment of product quality according to peer reviewers are presented in table 7.

Table 7. Results of evaluating product quality by peer reviewers.

\begin{tabular}{lllll}
\hline Aspect & $\begin{array}{l}\text { Ideal } \\
\text { highest } \\
\text { score }\end{array}$ & $\begin{array}{l}\text { Score of } \\
\text { assessmt } \\
\text { results }\end{array}$ & $\begin{array}{l}\text { Percentage of } \\
\text { ideals (\%) }\end{array}$ & Quality \\
\hline Learning & 28 & 26,3 & 94,05 & SB \\
Display & 20 & 18,3 & 91,67 & SB \\
Linguistic & 12 & 11,3 & 94,44 & SB \\
Total & 60 & 56 & 93,39 & SB \\
\hline
\end{tabular}

Description: SB (Very Good).

The quality of flipbook based on flash carbohydrate test material according to peer reviewers is very good with a percentage of $93.9 \%$. The results of product quality assessment according to the teacher are presented in table 8 .

Table 8. Results of product quality assessment by teachers.

\begin{tabular}{lllll}
\hline Aspect & $\begin{array}{l}\text { Ideal } \\
\text { Highet } \\
\text { Score }\end{array}$ & $\begin{array}{l}\text { Score of } \\
\text { Assessmet } \\
\text { Results }\end{array}$ & $\begin{array}{l}\text { Percentage } \\
(\%)\end{array}$ & Quality \\
\hline Learning & 28 & 21 & 75,00 & $\mathrm{~B}$ \\
Display & 20 & 15 & 75,00 & $\mathrm{~B}$ \\
Linguistic & 12 & 9 & 75,00 & $\mathrm{~B}$ \\
Total & 60 & 45 & 75,00 & $\mathrm{~B}$ \\
\hline
\end{tabular}

Description: B (Good).

The quality of flashbook based on carbohydrate test material according to the teacher is very good with a percentage of $75.00 \%$. Furthermore, the products presented in a limited manner to students to get responses from students are presented in table 9.

Table 9. Student responses to flash-based flipbook products.

\begin{tabular}{lllll}
\hline Aspect & $\begin{array}{l}\text { Ideal } \\
\text { Highest } \\
\text { Score }\end{array}$ & $\begin{array}{l}\text { Score of } \\
\text { Assessment } \\
\text { Results }\end{array}$ & $\begin{array}{l}\text { Percentae } \\
(\%)\end{array}$ & Qualiy \\
\hline Pembelajarn & 24 & 20,10 & 83,75 & SB \\
Tampilan & 32 & 26,40 & 82,50 & SB \\
Kebahasaan & 8 & 6,80 & 85,00 & SB \\
Motivasi & 16 & 14,60 & 91,25 & SB \\
Total & 80 & 67,90 & 85,60 & SB \\
\hline
\end{tabular}

Description: SB (Very Good).

Flash-based flipbook products get an assessment from students of $85.60 \%$.

\section{Discussion}

This research is included in the development research (Research and Development) which is divided into three main stages, namely the design of flash-based flipbook using Macromedia Flash and microsoft word 2010 developer software, carbohydrate test practicum with taking pictures, and product trials on teachers and students who validated by experts and peer reviewers. 
In the first phase of the research, the development planning stage. This development phase uses Macromedia Flash and Microsoft Word 2010 developer software. The second stage is the carbohydrate test practicum in the laboratory. Alternative sources of carbohydrates used are avocado seeds, durian seeds and jackfruit seeds which are seeds that are often found in everyday life, but apparently students do not know that the seeds contain carbohydrates.

In the carbohydrate test barfoed test, benedict test, and iodine test were carried out. The first test is barfoed test is a qualitative test of carbohydrates using reagents in the form of a solution containing kuprisulfat and acetic acid in water In the experiment, it was found that in the three test materials there were brick red deposits. The second test is benedict test is a qualitative test of carbohydrates using reagents in the form of solutions containing kuprisulfat, sodium carbonate and natriumsitrat. In the experiment, obtained in avocado seeds there were brick red deposits, in durian seeds there were yellow deposits and on jackfruit seeds there were green deposits. The third test is iod test which is a testing method for polysaccharide molecules. In the test results, the material samples showed positive results on the iodine test, indicated by the change in color to blackish blue.

The assessment results provided by material experts and media experts showed that flash-based flipbook has very good quality with percentages of $90.87 \%$ and $88.10 \%$ respectively. The next assessment was carried out by peer reviewers as many as 3 people and obtained a percentage of $93.39 \%$ with very good quality. While the quality of flash-based flipbook according to the teacher is good with a percentage of $75 \%$. The results of the analysis of student responses to flash-based flipbook are of very good quality with a percentage of $85.6 \%$. According to students, the flash-based flipbook that was developed can add insight so that it can motivate students to learn. Based on the overall discussion that has been described, that flashbook based on carbohydrate test material has fulfilled the requirements as a teaching material for science learning.

\section{CONCLUSIONS}

1. The development of flash-based flipbook media regarding carbohydrate substance testing meets the criteria of good media quality successfully developed through the main stages of carbohydrate test practicum, product development and testing.

2. The results of the assessment of the development of flash-based flipbook based on the assessment of experts, peer reviewers are included in the very good category. Whereas for teacher assessment included in the good category. Student responses to flash-based flipbooks included in quality are very suitable for use as learning resource media with an ideal percentage of $85.60 \%$.

\section{REFERENCES}

Arsyad, Azhar. 2008. Learning Media. Jakarta: PT. Raja Grafindo Persada.

Chandra. 2014. 7 Hours of Learning Flash MX for Laymen. Palembang: Maxikom.

Degeng, I Nyoman Sudana. 1989. Teaching Science of Variable Taxonomy. Jakarta: Department of Service and Culture.

Dzamarah, S.B and Aswan, Zain. 2006. Teaching and Learning Strategies. PT Rineka Cipta: Jakarta.

Gestaning, Guni. 2014. Development of Media Booklet Drawing Various Types of Pants on Basic Competencies of Drawing Pants for Students of SMK N 1 Jenar. (Essay). UNY: Yogyakarta.

Hasrul. 2011. Design of Animated Learning Media Based on Adobe Flash CS3. Media Technology Journal. 3 (2). 